\title{
PROPOSAL OF THE LAW AND JUSTICE (PiS - Polish abbrev.) TO AMEND THE ACT ABOUT THE DIRECT CHOICE OF A VOIT, MAYOR AND PRESIDENT OF THE CITY. OPINIONS ABOUT POSSIBLE EFFECTS AND CONSEQUENCES
}

\author{
by Joanna Marszałek-Kawa
}

\begin{abstract}
INTRODUCTION
In democratic legal systems there is a wide variety of instruments which profoundly affect the composition of future parliaments. They can cause significant changes in final results of both the parliamentary and municipal election. Due to them political parties can improve their position in emerging legislatures (gmina councils, poviat councils or sejmiks of the voivodeship), or even, I mean smaller formations in the first place, can guarantee any representatives in the chamber (council, sejmik). Politicians make use of these instruments most frequently in the face of the oncoming election. These mechanisms allow, on the grounds of binding law, to cause a result much worse than expected for the opposition or formations competing for power. In countries with deeply rooted democracy, it is most often a good political habit that makes any changes in the Electoral law take place long from the election. In our political reality, however, it is a rule that the election campaign is accompanied by auctions on legal grounds. Namely, changes in the borders of election districts take place, vote calculation methods are modernised so that they would be naturally beneficial for those who carry out such normative transformations.

The aim of this article is to present one of examples illustrating such machinations concerning election acts, namely actions aiming at "the exchange of generations" in self-governments, as it was suggested by politicians in favour of these transformations. Taking the political context into consideration, however, in which attempts to
\end{abstract}


implement these amendments were made, (eventually the act about the direct choice of a voit, mayor and president of the city ${ }^{\prime}$ in this area was not amended due to the lack of support) one could wonder about the real intentions of the initiators. Was it really about breaking off with the past, breaking local family and social relations, ousting voits "autocrats", or should it be regarded as a symptom of struggle between the young and the old? Did the initiators of changes in the electoral law assume that leaders with relevant knowledge and competences are necessary for effective self-government in new reality after the accession of Poland to European Union, or it was it just an effort of searching positions for their staff? These are the queries to which I am going to find answers in this article, by quoting politicians, self-government representatives as well as doctrine representatives.

To have a full picture, it is necessary to remind one at this point who can become a voit, mayor and president of the city on the basis of the binding law. According to the act about the direct choice of a voit, mayor and president of the city as of June 20, 2002, everyone entitled to vote for gmina council has the right to vote for a voit, mayor and president of the city in a given gmina district (active right to vote). On the other hand, every Polish citizen entitled to vote for gmina council, who completed his $25^{\text {th }}$ year of life at latest on the election day, has eligibility right (passive right to vote). A candidate does not need to constantly reside the gmina district where he candidates. It is impossible to candidate for this position in another gmina district at the same time.

During the last few years a voter, even moderately interested in the Polish political stage, has got used to changes performed in election act by consecutive governing teams. The Law and Justice ${ }^{2}$ has presented several ideas in this field. One of them was aiming at a new decision about who is and who will be entitled to the passive right to vote in the municipal election. According to this assumption, the people who have held the office of a president, voit or mayor for at least two terms so far, would be deprived of the right to run for this office again in the following election. According to the initiators, thanks to such a solution it will be possible to break connections, which have dominated numerous self-governments.

Marek Kuchciński ${ }^{3}$ has emphasised several times that this idea was announced for the first time ten years ago during work on amending electoral law run by president Aleksander Kwaśniewski, and then it was subjected to strong criticism.

1 "Journal of Law" 2002, No. 113, item 984 with subsequent amendments.

2 E.g. the idea of introducing into parliamentary election voting rules based on a German model, so called mixed electoral law.

3 Vice-chairman of the PiS Parliamentary Club. 
This idea returned again during the Sejm session of the fourth tenure when discussing amendments to self-government acts in the Local Self-government Council. ${ }^{4}$

Przemysław Gosiewski (PiS) when explaining the reasons for looking for new solutions in self-government law stressed that so far electoral regulations serve so called connections. In his opinion, the idea in question is not meant to ristrict the rights of residents to decide, but it is supposed to prevent the same people from winning in the subsequent election again. Gosiewski disproved the fact that politicians of the PiS are exclusively interested in finding offices for their politicians claiming that the new law should protect democracy better. He pointed out that a low turnout serves strengthening old connections where a voit has held his office since the 1970s in some gmina areas where he had been the head of gmina earlier. ${ }^{5}$

This opinion is shared by prime minister Jarosław Kaczyński (PiS), who in one of interviews stated that implementing restrictions within terms of voits poses no coup d'etat of autonomy, because autonomy can function well both in the presence of such a restriction and without it. ${ }^{6}$

According to Maciej Eckardt, a politician and journalist' ${ }^{7}$ nothing else can serve authority better than its periodical ventilation. (...) In healthy local communities there must be circulation of the elite. Everybody knows that a good plan requires "rotation of crops", particularly in politics. (...) In practice we often deal with local duchies where a voit, mayor and "satrap" are proverbial "oppressors", exercising family-colleague politics in which there is no room for competition whereas everything is subjected to a group's business (...). ${ }^{8}$

The idea of reducing to two tenures the offices of a voit, mayor and president of the city caused a real stir in the circle of self-government politicians. The solution proposed by the PiS was called “coup d'etat of democracy”, „cheap populism”, „limitation of the right to vote". It was emphasised that realisation of a new electoral solution would mean, it was the case of Silesia, that $80 \%$ people with a long-term professional experience as well as working for self-governments would miss the chance to be elected again.

During the $19^{\text {th }}$ All-Polish Conference of Voits, Mayors, Presidents of cities, Starostes and Marshals, organised in Poznań on June 27-28, 2006, the representatives

4 I. Kacprzak, New Idea of the Law and Justice about Self-government Election, "The Western Journal", 2.02.2006.

${ }^{5}$ Ibidem.

${ }^{6}$ www.samorząd.pap.pl 25.05.2007.

7 At the moment of giving the interview Maciej Eckhardt was a member of domestic leaders of the LPR (the League of Polish Families), currently in the PiS.

${ }^{8}$ R. Jaworski, What serves Authority? Interview with Maciej Eckardt, "Informator Samorządowy", 6-20.02.2006. 
of Polish Metropoly Union, the Union of Polish Towns, the Society of Rural Gmina of the Republic of Poland (RP), the Society of Polish Cities, the Society of Polish Poviats and the Society of the RP Voivodeships, they expressed their opinions about the proposal of amendments in the municipal electoral law as well as in the system of territorial self-government units. Signatories of the document in question decided that the new solution has a clearly passing character. There are no substantial arguments behind such a decision, still it is directly connected to the oncoming municipal election.

On February 20, 2006 the Society of Rural Gmina of the Republic of Poland presented its opinion about the idea proposed by the Law and Justice. From this idea it followed clearly that local politicians anxiously and with indignation received the concept of legal regulations which limit the possibility of holding the office of a voit, mayor or president of the city to two terms. According to the representatives of the Society, the proposed legal solution will prevent citizens from a free choice of candidates whereas the best members of the self - government, who enjoy the mandate of community trust will be exposed to "banishment" for no content-related reason. Signatories of the document regarded it as an evident coup détat of democracy as well as civil rights guaranteed by the Constitution of the Republic of Poland. It was also emphasised that the greatest development successes of Polish gmina districts were present where executive power continuity is guaranteed. (...) The knowledge about a gmina district in the field of its developmental potential, residents and possibilities of gaining outside funds for financial support of planned investments, is essential to indicate the directions of development. Additionally, members of the self-government wondered whether the new idea of ruling parties does not mean a proverbial "cash robbery", seeking additional financial means for realisation of strategic ruling targets at the cost of gmina stagnation.

The opposition politicians of the fifth administration Sejm ( $\mathrm{PO}$ - the Civic Platform Party, SLD - the Democratic Left Alliance and PSL - the Polish Peasants Party, whereas Self-Defence of the Republic of Poland did not approve of the idea either) did not spare bitter words, either. It was stressed during debates that the idea of limiting the term of office in self-governments is not a new one at all. This solution was proposed and discussed many times in the past, still never met much affirmation. Bronisław Komorowski even stated, sharing the same opinion with prof. Jerzy Regulski, that nowhere else in Europe there exists a term of office in self-governments or similar restrictions. ${ }^{9}$ In his opinion the Law and Justice, by realisation of this solution, wants to deprive widely experienced people, who enjoy their community trust, of the possibility of ruling. The SLD member of parliament Witold Gintowt-

${ }^{9}$ Komorowski Criticises the Idea of the PiS, “The Baltic Daily", 13.02.2006. 
Dziewaltowski claimed that under the cover of office term, the PiS wants to remove competition from self-governments, where the party sees no chances of election winning. ${ }^{10}$

The PSL chairman Waldemar Pawlak pointed that the implementation of limitation of office term in relation to a voit, mayor and president of the city means violation of constitutional rights and freedom. This leads to a political elimination of people who are most effective and honest subject to a social evaluation and verification in the election."

Professor Jerzy Regulski' ${ }^{2}$, an unquestionable authority in the field of self-government noted in his report that multi-term of the voit, mayor or president of the city office causes no problems in practice. Regulski stated that the general direct election that takes place every four years is a sufficient mechanism of verifying the community trust of the self-government members ${ }^{13}$. According to Regulski, limitation of the term of office could cause quite the opposite results:

a. Legal and constitutional results - they would restrict the passive right to vote of the people who held two terms of the office of a voit and mayor as well as the active right of citizens devoid of a free choice of candidates they trust. The Constitution of the Republic of Poland evidently adopts the equality rule of all citizens. Consequently, eliminating the chances of choice on account of the so far public activity shall be regarded as a serious violation of the constitutional equality rule. Proposed statutory amendments will certainly eliminate the people who have already proved in the self-government activity, and so they will prevent the civic society from development.

b. Social and civic results - leaving by the legislator to local communities the right to self-determination in their own matters decides about the essence of self-government. Local communities need to be guaranteed the possibility of choice,

10 Ibidem.

11 www.pawlak.pl, 25.05.2007.

12 President of the Local Democracy Development Fundation is one of the initiators of the territorial self-government in the Third Republic of Poland. In the period from 1989 to 1991 he directed parliamentary works on the self-government reform so that, as the Government Representative for Territorial Self-Government Reform, He could coordinate its implementation. Between 1992 and 1997 a regular representative of Poland beside the European Council in Strasburg. Between 1998 and 1999 president of the Council for State System Reforms beside Prime Minister. An outstanding expert of self-government and town planning. Published more than 200 books and dissertations, lectured at 78 universities.

13 J. Regulski, Report entitled: Possibilities and Consequences Resulting from the Regulations that Reduce Holding the Voit, Mayor or President of the City Office to Two Terms. Preliminary Comment, Warsaw, 22.02.2006. 
c. Functional results - introducing restrictions in the area of the term concerning the discussed offices undeniably would cause a real organisational shock. This would lead to destabilisation and worse functioning of the self-government. At this point it would be advisable to point at a well grounded postulate of extending the term of the voit, mayor and president of the city office, which would be helpful due to necessary realisation of long-term financial programs related to the UE money - the responsibility of an initiator for his programme would be desirable whereas some changes in the office of voits during the program realisation cause an immense danger. ${ }^{14}$

Taking the above into consideration, Jerzy Regulski decided that introducing new regulations by the legislator in this range is groundless for many reasons:

- groundless in content-related terms thus unnecessary,

- might break civil rights,

- might not be transparent for society as it is difficult to understand why good and reliable people are eliminated,

- might violate the basis of the self-government that depends on the right of local communities to a free choice of people who are entrusted with local problems,

- might decrease the quality of local administration,

- might bring results as late as in 2014, because the law is not retroactive. ${ }^{15}$

This opinion was shared by another expert in self-government, Norbert Honka from the Opole University, who believes that it is not right to change voits, mayors or presidents of cities who realise their tasks well. After all, they are subject to the opinion of most voters. According to Honka new power frequently means a new personnel order, lack of experience and waste of time for necessary learning. The people, estimated unfavourably, are eliminated by voters. ${ }^{16}$

Representatives of the doctrine emphasised that the municipal election politicization and thus the self-government politicization will become a consequence of introducing a new solution to the right to vote. Marek Mączyński argued that $t$ is the voters' decision that should be the ground for implementing possible changes in "the local elite" and not legislator's efforts. ${ }^{17}$

${ }^{14}$ Ibidem.

${ }^{15}$ Ibidem.

${ }^{16}$ I. Kacprzak, New Idea of the Law and Justice about Municipal Election, "The Western Daily", 14.02.2006.

17 Ibidem. 
According to Michał Kulesza, restricting the office term of the voit, mayor and president of the city is a solution which shall aim at "the elimination of long term political enemies who enjoy the community support ${ }^{18}$.

However, even among members of the self-government one could find a few individual supporters of the Kaczyński brothers party new idea concerning changes in the self-governed law. This indicated that so far it has been incredibly difficult to develop a political career by municipal politicians elected in the majority election. The new solution, however, causes that also former presidents of the city, mayors and possibly voits, who enjoy the community support and trust due to their wide experience and competences, will follow this path of development. The time of introducing the changes caused certain doubts even in the circle of supporters of this idea, though. The pre-election period and introduced modifications of the binding law considerably weakened the arguments presented by the PiS politicians; some asked about the real intentions of "the ruling party". ${ }^{19}$

At this point it is advisable to mention a surprising statement of the Civic Platform Party leader, different from the majority of opinions in this party. According to Donald Tusk, the rule of the office term restriction would be necessary because, as he stated in the interview for "The Kartuska Daily" "(...) usually stewards of gmina districts tend "to prevail" after eight years (... $)^{20}$

To conclude one should remind that finally the ruling party did not manage to introduce designed amendments. The necessary majority in the Sejm failed whereas the opposition of the self-governed environment made followers of the idea surrender to their arguments. Probably, this does not mean that there will not spring up another political debate in this field in a few years' time. After all this topic is quite popular with mass media. Taking Polish reality into consideration, one may suspect that unfortunately this will happen in the face of the following municipal election.

\footnotetext{
18 www.wiesciwyborcze.pl

19 I. Kacprzak, New Idea of the Law and Justice about Self-government Election, op.cit.

${ }^{20}$ Discussion of R. Leszkowski with D. Tusk, www.gazetakartuska.pl, 10.10.2007.
} 


\begin{abstract}
SUMMARY
To sum up, there arises another question instead of an answer: how significant is the experience gained during long-term work in the self-government and residents' trust?

Is it necessary to have an extra asset in the form of a party card in order to fulfil one's functions effectively? Is there not too much politics in the self-government? There is no doubt about the fact that depoliticization of the self-government would be a significant enhancement, not changes towards a totally different direction. I suppose the initiators of the presented modernisation of the municipal right to vote forgot about these dilemmas. Taking the above reflections and opinions into consideration, one would rather design changes in the field of extending the office of a voit, mayor and president of the city, remembering about the reality, in which members of the self-government work nowadays. Preparing financial investments from the EU funds is a long process. It is worth discussing a rule concerning the responsibility of a clerk, who prepared such investments and is in charge of their realisation, it should not concern his successor elected in so called municipal election in the meantime. This idea requires a deeper analysis, disputes in the circle of the selfgovernment members, politicians, representatives of the doctrine, naturally not soon before the following election, but in a calm and rational atmosphere.
\end{abstract}

